\title{
EDUCATIONAL POLICIES (1947-2009) OF PAKISTAN AND INTEGRATION OF ISLAMIC VALUES AMONG SECONDARY LEVEL LEARNERS: AN EVALUATIVE STUDY
}

\author{
Dr. Waqar Un Nisa Faizi ${ }^{*}$, Dr. Wilayat Bibi ${ }^{\dagger} \&$ \\ Dr. Farah Khan*
}

\begin{abstract}
Educational policies are being made in any country to support more rigorous educational programs as evidenced in history. In all policies and plans, some important foundations are considered as essential for the required level of learners. Being a Muslim nation, Pakistan has always thought of a strong base of Islam because it is a fundamental element in the preparation of any policy. This study aims to provide a review of each educational policy setting from 1947 to the 2009 instructive plan. The main findings of the study are that all of these plans have some good suggestions for providing information on Muslim qualities, but ironically, steps related to Islamic knowledge are taken for granted. Only 1978 policy has given stress on Islamic Education and the establishment of institutions like Maktab School etc. So in the light of the evaluation, it is suggested that strong preparations has to be made to give greater attention to Islamic knowledge for secondary level learners because multicultural development occurs at this stage and it is necessary for good student behavior.
\end{abstract}

Keywords: Education, Policies, Islamic Values, Secondary Level

\footnotetext{
Assistant Professor, Department of Education, Islamia College Peshawar.

$\dagger$ Assistant Professor, Department of Education, Shaheed Benazir Bhutto Women University Peshawar.

* Assistant Professor, Institute of Education \& Research, Women University Mardan.
} 


\section{Introduction}

Constructive policies provide a solid foundation for any Educational setup. To become an Islamic state Pakistan had to make such kind of strategy that colored in Islamic absolute shadow, because people had demanded Pakistan to set their lives according to Islam's standards. So the organization of educational policies of Pakistan needs to be evidenced by the Islamic way of life, but there is not achieved much after nearly 73 years of its inception. From the instigation of Pakistan till now, there have been several such policies/arrangements developed by various Governments. Overall the setting of this focus is given in following figure:

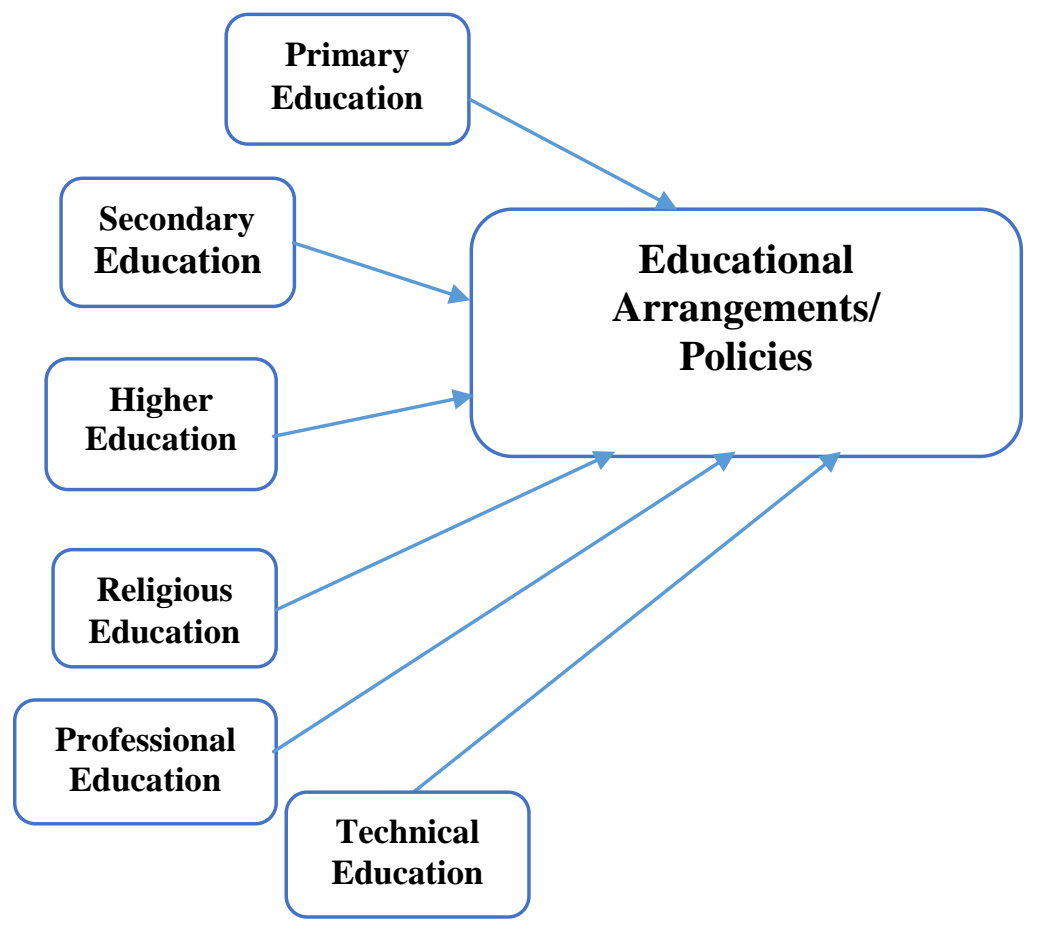

Figure 1

In all the constructive approaches/planes, there had an outsized number of proposals given to make an educational framework in Islamic color. For various reasons these techniques couldn't find a useful way. Rehman (1984) viewed this in following perspective,

"From the primary policytill now, Islamiyat and Pakistan studies are considered compulsory for secondary level learners but the results of our entire education system remain elusive." 
According to Rehman \& Khan (2018) both the systems of Education (religious \& modern) failed to reform the society or bring about any change for the betterment. Religious institutions created religious extremism, and modern institutions create materialism, drug culture and moral degradation. To resolve all these issues it is necessary to revise the whole curriculum, revisit the existing teaching methodologies and focus on the characterbuilding of students.

\section{Research Objectives}

1) To learn how much integration of Islamic Values among secondary level students is done in the Pakistani educational system.

2) Examining Pakistan's educational plans/policies/strategies (1947-2009) related to the integration of Islamic values.

3) Providing a brief discussion of the inclusion of educational strategies and policies on integration

\section{Research Questions}

1) How much the inclusion of Islamic Morality/values in educational programs set out in Education policies (1947-2009)?

2) To what extent have the Islamic Educational Programs utilized in Education policies for secondary level learners (1947-2009)?

\section{Hypothetical Basis of National Education Policies/Strategies}

Before examining the war on the Islamizing training in Pakistan, we might wish to take a primary check that what progress is being taken by the educational policies and what suggestions are being given for this purpose. In these policies, the main target of Islamic moral values training are mentioned as:

\section{1) Basic Educational Meeting in 1947}

The first meeting was held on 27th November 1947. This became the idea for Pakistan's educational planning. On this basis, a future strategic plan has been developed. A crucial point of the meeting was to recommend that a constructive framework would be linked to Islamic life concepts. The meeting has a crucial part of the Quaid-e-Azam message. Minister of education Mr. Fazal Ur Rehman read that message,

"For nearly 100 years we had been evacuated from western countries. Without a doubt, our future depends on the thought of preparing our youngsters. For the aim they're going to become productive members of Pakistan's future society. Intrinsically they're going to be flawed in several fields and should increase the 
respect of their nation. The essence of our academic framework must be supported by the qualities of Islam. For this reason human solidarity and social equality got to be taken under consideration." [Management of Pakistan (1947) Proceedings of Pakistan Educational Meeting, p. 5]

Mr. Fazal Ur Rehman, in his speech gave tons of concerns to form Islamized education,

"Our academic framework must be governed by Islamic standards."

[Pakistani Legislature (1947) Continuing Educational policy of Pakistan, p. 6]

Its recommendations organized as twenty-four goals. Two of them are identified with Pakistan's divisive educational framework on the Islamic hypothetical basis.

[Administration of Pakistan (1947) Continuation of Pakistan's Educational Meeting, p. 44]

\section{2) National Commission on Education 1959}

At the time of Mohammed Ayyub Khan on December 3, 1958, a commission was appointed under supervision of Syed Muhammad Sharif. The commission aimed to present a couple of proposals for the reconstruction of Pakistan's educational framework. The commission presented its report in August 1959. Muhammad Ayyub Khan then gave his remarks at the event.

For the importance of the Islamic education, the commission release details of instruction on these terms, "Our educational framework must play a crucial role in ensuring that those ideas originate with Pakistan."

[Pakistan Legislature (1959) Report of the Commission on Education, p. 10]

As shown by the report, religion places great importance on the enlightened history of some people. In middle and upper grades the subject of Islamiyat must be enforced on adults. From the start they have to be taught the Quraan (Nazira). Within the subject of Islamiyat, themes about Quraan, Seerat-Un-Nabi, Islamic history got to be included. Choose those Ayaat (stanzas) from Holy Quraan that are completely related to prepare perfect Muslims. Strong training requires the enforcement of undergraduate $\mathrm{A}$ and $\mathrm{O}$ level students. A special Islamic information center is required to be located within the varsity premises, where research offices need access. The commission gave recommendations supported Islamic research,

"Educational officials should visit high schools and build Muslim data. Muslim investigators must be sent to Muslim scholars."

[Administration of Pakistan (1959) Report of the Commission on National Education, p. 211] 
In the end commission added that the teaching program of the Maktabs, Madrasahs and Darul Uloom aren't linked to contemporary needs and only rigorous and structured courses are taught there. In developing this example the commission proposes that "The quality of teaching must be improved in these centers."

[Administration of Pakistan (1959) Report of the Commission on National Education, page 279]

\section{3) Educational Approach 1969}

In September 1969 the Air marshal Noor Khan circulated a variety of proposals submitted by the government for supervised education. The report was made available only at $1 / 4$ of the year. An outsized part of recommendations were as same as the precious policies. Henceforth with a specific focus they provide the importance of Islamic identity.

"Islamiyat had provided the required status within the tenth class. It had been also suggested that Islamic research should be seen as important at the varsity level also because of the consequences of this specialize in legal issues. In Islamic organizations science and arithmetic subjects need Islamic bias. All the standard schools must be improved regarding inculcating Islamic ideology among learners."

[Ministry of Education (1969) Proposals for Further Education Policy, p. 2]

\section{4) Educational Arrangement 1972-80}

During Zulfiqar Ali Bhutto's administration, Educational minister Hafeez Pirzada introduced an educational plan in March 1972. In his speech, the Pakistani leader expressed his unacceptable views on past educational arrangements.

They have chosen the exposition of Pakistan's theory as a start line for training. As:

- Application of Pakistan's original hypothetical theory and links it to national Islamic prosperity.

- The educational approach considered the importance of rigorous training from a practical perspective. This approach concludes that we must not keep the Islamiyat, the remainder of the constructive provision but to strengthen it through training. Summaries of strategy are:

(1) For Muslims, Islamiat is going to be mandatory until the tenth grade.

(2) Radio and TV will provide maximum time for the recitation and translation of the Holy Quraan for new teaching structure.

(3) The strong educational institutions under Islam will remain in their current state and continue their work as Maklabs, Madrasahs and Dar Ul Ulooms.

[Educational policy (1972) Institute for Educational Research Hyderabad, p. 3] 


\section{5) Education Plan 1978}

Education Secretary Dr. Qazi announced an educational plan in October 1978 during the legislature of General Zia Ul Haq This approach is additionally called the tutorial provision of Islam through informative gatherings. Educational Minister Mohammed Hooti examined the Pakistan's education with these words,

"The foundation of Pakistan came unquestionably to the Muslims of subcontinent to lay down their lives as cited by the Quraan Hadith without pressure. I assure you that through a national plan the training obtained through Islamic principles will remain in line with the social needs of the state."

[Pakistan Administration (1978) National Education Policy, p. 1]

The recommendations of this approach is completely visible within the Islamic shack.

[Govt. of Pakistan (1978) National strategy of Education, p. 59]

The national approach introduced the simplest version which makes it a national strategy. These suggestions are:

(1) Islamiyat shall be included at all levels of education as a compulsory subject.

(2) In the schools and Universities the teaching of Arabic is going to be corrected.

(3) A full-time Sharia employee's center shall be created at Quaid-e-Azam University.

(4) 5,000 mosque schools are going to be accessible to students from across the country.

(5) 5,000 Muhallah schools are going to be designed for female students.

(8) All Madrasahs, Maktabs and Darul-Ulooms are going to be given full importance as the other formal educational institutions.

\section{6) Educational Approach 1992}

This policy was reported by minister Mr. Fakhar Imam. The legislature of Mr. Nawaz Sharif was used. All items were announced under 26 sections. The disappointments of past policies were talked about at the start of the meeting. To facilitate this approach, separate distinctive meetings were held altogether districts. The important point of this strategy was to make an efficient educational framework, which suggest the program that the Muslim Pakistanis can access within the 21 st century. As they said,

"Real results couldn't be achieved just by allowing Muslims to continue training. This strategy proposes a system where learners can better understand the true history of Islam. "

[Govt. of Pakistan (1992) National Strategic Plan, p. 8] 
To receive ethical training it's recommended that the Islamic view must be reflected within the system of teaching. During the hour of meeting in schools, colleges and universities it'll be mandatory to recite the Quranic Surahs. To accomplish this reason the Nazira-e-Quraan will continue from a pre-primary stage.

\section{7) Educational Approach 1998-2010}

The new pedagogical model of 1998 to 2010 was connected within the progressive realization of Islamic progress and social development. This approach repeated the goals of the 1947 educational meeting. The last one came in 1992 during the tenure of Nawaz Sharif. Within one year of the approval of this strategy, his administration was excused. After regaining office in 1997, Nawaz Sharif investigated the issues. At this event, Mr. (Retd) Sayed Ghous Ali Shah, an education minister said:

"Education immediately appeared to be the key to good policy

for social and financial advancement of country. Pakistan's philosophy undermines two important legislative obligations:

- Firstly the training is going to be given for hospitable to all.

- Secondly it'll empower them to seek out self-developed people that are focused thereon in Islam.

[Govt. of Pakistan (1998-2010) Ministry of Education, New Educational Policy, p. 1-3]

These obligations are almost like the teachings of the Quraan, which perceives the arrangement of learning as a privilege of the person. Despite the fact that previous approaches are integrated into Islamic training yet those strategies haven't proposed the way to translate the Islamic belief system into our informative framework.

Pakistan isn't a secular state but an Islamic nation, although, for the past fifty-one years, it's not isolated itself from the pilgrims. While we are talking about the solid elements of the new policy, this angle can't be ignored.

[Govt. of Pakistan (1998-2010) Ministry of Education, New Educational Policy, p. 9-11]

There are several policy provisions regarding Islamic training:

- Teaching the Holy Quraan with translation will be introduced from class VI till class XII.

- The basic lessons of the Holy Quraan will be remembered in all subject areas.

- Connecting the existing input between the relevant training framework and the Deeni Madaris system. Deeni Madaris' educational programs will be developed to enhance career opportunities.

- Important and unusual books on Islam will be produced and distributed among Deeni Madaris for research and analysis.

[Govt. of Pakistan (1998-2010) Ministry of Education, New Educational Policy, pp. 12-13] 
As indicated by the plan the (IX-X) level is the visible bottom of the entire training framework. On the one hand, it provides middle-class employment in the economy and on the other hand, it supply more important training levels. The kind of high-quality education at this level, will bring the best professionals in social, financial and political fields.

[Govt. of Pakistan (1998-2010) Ministry of Education, New Educational Policy, pp. 37-41]

\section{8) Current Instructive Strategy 2009}

The Educational Policy of 2009 stipulates that the view of Islamic education in the secular system of education is a social change. As enshrined in the Constitution of Pakistan, every step will be taken to empower the Pakistani Muslims, to organize their lives according to the fundamentals of Islam. They might be empowered to comprehend the significance of life as indicated by the Holy Quraan and Sunnah.

[Govt. of Pakistan (2009) Ministry of Education, p. 30-32]

\section{Methodology of Study}

This historical study is evaluative in nature. An evaluative study is a systematic assessment of the value or amount of time, effort and resources used to achieve a purpose. The researcher examined Pakistan's educational policies (1947-2009) relating to the integration of Islamic knowledge among secondary level students and also examined the implications of these programs related to Islamic knowledge. For this purpose the Educational Policies of Pakistan (1947-2009) and concerned articles were used as primary data. An attempt has been made in this study to analyze both the educational policies objectively and critically and to explore a productive and feasible way out.

\section{Reasonable Application of Educational Policies / Strategies Concerning Islamic Values}

Quaid-e-Azam was strongly in favor of making the draft, indicated by the Islamic theoretical framework. We can check his gravitational strength as he organized the educational board of trustees in 1946 closest to Pakistan's establishment containing notable Muslim masterminds. They decided at its first Aligarh meeting that Pakistan's general educational order would be a reflection of the Islamic thinking. Subsequently a plan was prepared for Pakistan in November 1947 which was set up with the mindset of Pakistani population and it was even more surprised when people from the minority similarly cast votes for cooperation. In 1951 a 5-year plan was made in which the ruling and ordinary government schools and colleges made the teaching system modern with the Pakistan basis. They similarly 
released that the teaching must be connected with religion but these efforts have not yielded any natural products. This situation lasted until 1958. In 1959 an educational report stated that training as indicated by Islam is necessary however in the 27 sections of the report only one part was related to value training and in the other 26 sections there was no single word for Islam. Before starting the report, questionnaires distributed across the nation to gather views regarding the plan. In that survey out of 203 questions, only three were mentioned about Islamic training. That scenario suggests that the idea of the strategy was not Islamic. Only two things had brought indications. The first is that the Islamiyat will be compulsory until the eighth grade and after that in future classes it will be discretionary. Secondly, Islamic research organizations will also be formed.

Political mistrust resurfaced in repeating the educational policy of 1969. Islamiyat thus gained the power to the tenth rank because of this approach. Even though the educational strategy of 1972-80 was highly developed, evolving with the Islamic training, but it did not prove to be superior to previous strategies. It organized the planning of Islamiyat and Pakistan studies on the reality of the current crisis and also confirmed new textbooks for the study alongside making Islamiyat a mandatory subject until the tenth level. It was envisaged that Arabic languages would have six to eight categories. The educational setting of 1978 embraced the real concept of the Islamic teaching encounter that began in 1947. The legislature approved all developments in the globalization of the Islamic command held in Makkah. Pakistan also took an interest in that meeting. In this way, the work began to provide the Muslim community with a framework for education. All antiSemitism in the education system was banned. The study of Islamiyat and Pakistan studies has reached to the graduation level. Arabic gained compulsory subject status in the sixth through middle grades. Two important developments were taken as a result of that arrangement. The first was to improve the reading material and to revise the teaching program. The point of the program was the modernization of the entire educational system, intending to shed light on the Islamic ideology and achieve the goal of the state of national unity.

The 1992 educational policy has also given rise to Islamic culture but sadly would not have given the power due to administrative reasons but some parts of it become practicing, like the recitation of the Quraan in the morning at schools, colleges, and universities. Nazira got the status of compulsory at the primary stage.

The new educational policy of 1998-2010 was a positive impact of contemporary management practices, taking advantage of all national and international researchers.

In case of 2009 policy, we can say that from a practical point of view, the study set up for Islamiyat is not entirely different from previous 
strategies. Hence, it repeated all recommendations related to religious education given in previous policies.

\section{Discussion}

Education is the most effective element of any society and Education and faith are interrelated. Sometimes they are considered to be features of a single coin. Chaube \& Chaube (1996) argue that in lifetime a man wishes religion to be peaceful and strong. Particularly when we speak of formal education, its importance is often over-emphasized. According to Hemchand (2009) formal education is a narrative process that creates a valuable human education. The explosion and rapid passing within the demographic data will create some artificial problems. This relevant guide can be given to the new generation by educating them on values. According to Aggarwal (2003) values are part and parcel of the philosophy of the world. They are the guiding principles of health that can be suited to every development.

As a Muslim country, Pakistan likewise has to take the same steps of Islamic training through textbooks to secondary level learners. The Islamic view was based largely on Pakistan's demand in 1947. When the British finally decided to leave, Muslims sought a different place of origin to continue their lives in line with the Islamic ideology. Islam is not a religion that contains certain spiritual rituals but is the full scientific law of the transmission of direction in every walk of life. Under the government of Zia ul Haq textbooks have been compiled using provincial-based learning forums with the help of the Curriculum Wing. These tips then emphasized that they want to focus on a specific set of Islamic values. At the same time, the category of Islamiyat syllabus is divided among Sunnis and Shia at the Class IX and X level. Separate textbooks had been presented for students of the two casts but not the same editions were transformed into 1999. The Islamiyat curriculum places importance to instill Islamic identity in the children of Pakistan. In the case of Islamiyat, concepts involving Jihad have been developed in the framework of the struggle against infidels like fight against poverty, illiteracy or inequality. In addition, the official textbooks of Urdu, Pakistan Studies, Civics and other subjects at the secondary level are alike to have a large amount of content related to Islamic ideology.

Despite the textbooks one of the best strategies for providing Islamic information to teachers. The educational policy of 2009 has recognized and dealt with this space. The 2009 education policy indicates that Islamic teaching will be part of the training programs.

Quaid-e-Azam in many of its speeches refers to the principles and practices of the Holy Quraan. According to him Pakistanis must continue to fight against bribery, deception, self-determination and marketing of black.

In the seventy-two years, it was those four terrible evils that have plagued poverty and the well-being of the world. At this present time 
learning objectives will be achieved if the curriculum of Islamiyat, Pakistan studies and other subjects at the secondary level will incorporate the same content.

\section{Suggestions}

1) Educational strategies/policies should not be remained as a potter but practical steps should be taken to provide the right shade to these approaches.

2) Being a Muslim nation our entire educational framework should be shaped in the light of Islamic values.

3) Secondary level education must be reproduced. All imperfections must be protected by the State Office of Education. In particular the educational authorities should make minimal efforts to incorporate all Islamic information into the education system as per the suggestion of educational arrangements/policies.

4) It ought to be referenced in policies that from essential level till advanced education it is important to prepare the people as indicated by Islamic qualities particularly at secondary level to manufacture youngster's character decidedly.

5) Informative approaches for the role of careers, teachers and the community in promoting Islamic identity among learners must also be included.

6) To maintain a fundamental view of our country a large part of education policies and plans should consider Islamic knowledge as a priority by the mean of curriculum revision and effective teaching strategies.

\section{References}

Aggarwal, J.C. (2003). Theory \& Principles of Education. Vikas Publishing House.

Bhattacharya, S. (2003). Foundations of education. Atlantic Publishers \& Dist.

Chaube, S.P. (1996). Foundations of Education, 2E. Vikas Publishing House Pvt Ltd.

Government of Pakistan Ministry of Education (1978). Proceedings of instructive policy.

Government of Pakistan Ministry of Education (1959). Proceedings of Commission on National Policy.

Government of Pakistan Ministry of Education (1947). Proceedings of First Educational Meeting.

Government of Pakistan Ministry of Education (1969). Proceedings of National Educational Policy. 
Government of Pakistan Ministry of Education (1972-80). Proceedings of New Educational Policy.

Government of Pakistan Ministry of Education (1992). Proceedings of new Educational Policy.

Government of Pakistan (1998-2010) Ministry of Education, (1998-2010). Proceedings of New and recent Educational Policy.

Government of Pakistan Ministry of Education (2009) Proceedings of New and recent Current Educational Policy.

Hemchand, T.K. (2009) Problems of secondary education. Crescent Publishing Corporation.

Rehman, Fida Ur. \& Khan, Hashmat Ullah (2018), Role of Educational institutions, Social reformation and National integration in Pakistan, Journal of Religious Studies, University of Chitral, Pg. 16 \& 27. 